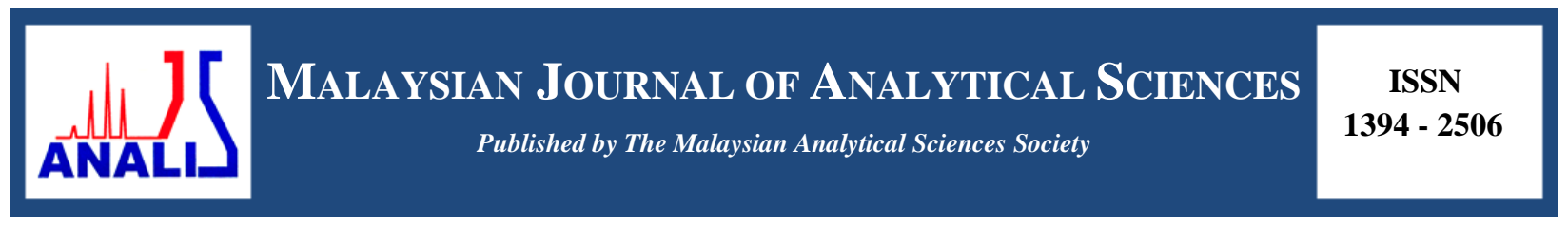

\title{
PREPARATION AND CHARACTERIZATION OF Ag NANOPARTICLES DECORATED WITH ZnO MICROSTRUCTURES FOR THE CATALYTIC PHOTODEGRADATION OF METHYLENE BLUE DYE UNDER UV LIGHT IRRADIATION
}

\author{
(Penyediaan dan Pencirian Ag Berstruktur Nanopartikel Diubahsuai dengan ZnO Berstruktur \\ Mikro untuk Penurunan Fotokatalisis Pewarna Metilena Biru di bawah Sinar UV) \\ Hartini Ahmad Rafaie ${ }^{1 *}$, Nur Azmina Mohemaed Safian ${ }^{2}$, Roslan Md Nor ${ }^{2}$, Yusof Mohd Amin ${ }^{2}$ \\ ${ }^{1}$ Faculty of Applied Sciences, \\ Universiti Teknologi MARA Pahang, 26400 Bandar Tun Abdul Razak Jengka, Pahang,Malaysia \\ ${ }^{2}$ Physics Department, Faculty of Science, \\ Universiti Malaya, 50603 Kuala Lumpur, Malaysia
}

*Corresponding author: hartinirafaie@pahang.uitm.edu.my

Received: 4 December 2016; Accepted: 1 December 2017

\begin{abstract}
Ag nanoparticles (AgNPs) decorated with $\mathrm{ZnO}$ microstructures was prepared by sol-gel method at different Ag concentration. The structures, composition and morphology of the samples were characterized by X-ray diffraction (XRD), electron dispersive X-ray spectroscopy (EDS) and field emission scanning electron microscope (FESEM). FESEM images shows that the samples were composed of $\mathrm{Ag}$ and $\mathrm{ZnO}$ with the particles size ranging from 100 to $500 \mathrm{~nm}$. EDS analysis confirmed that atomic \% increases as higher molar concentration applied with value of 5.6 at.\% and 16.1 at.\% for sample $0.05 \mathrm{M}$ and $0.1 \mathrm{M}$ AgNPs decorated $\mathrm{ZnO}$ microstructures. Methylene blue (MB) dye was used as a representative of dye pollutant to conduct the catalytic photodegradation activity. The AgNPs decorated with $\mathrm{ZnO}$ particles exhibited a better photocatalytic activity than the pure $\mathrm{ZnO}$ particles. The results show that an increasing of photodegradation rate constant, $k$ was obtained when higher concentration of Ag was applied to the $\mathrm{ZnO}$ with value of $0.016,0.026$ and $0.032 \mathrm{~min}^{-1}$ for pure $\mathrm{ZnO}, 0.05 \mathrm{M} \mathrm{AgZnO}$ and $0.1 \mathrm{M} \mathrm{AgZnO}$ nanoparticles, respectively. The increased of $k$ value in the presence of $\mathrm{Ag}$ was due to the prolonged lifetime of the photogenerated electron hole pairs in $\mathrm{ZnO}$ as a result of $\mathrm{Ag}$ nanoparticles acting as electron sink.
\end{abstract}

Keywords: Ag nanoparticles, zink oksida, sol-gel, photodegradation, methylene blue

Abstrak
Ag berstruktur nanopartikel (AgNPs) diubahsuai dengan ZnO berstruktur mikro pada kepekatan berbeza telah dibuat menggunakan teknik sol-gel. Sifat-sifat struktur, komposisi dan morfologi sampel diperincikan menggunakan pembelauan sinar$\mathrm{X}$ (XRD), spektroskopi Sinar-X sebaran elektron (EDS) dan mikroskop elektron pancaran medan (FESEM). Analisis FESEM menunjukkan sampel terdiri daripada $\mathrm{Ag}$ dan $\mathrm{ZnO}$ yang mempunyai saiz partikel antara $100-500 \mathrm{~nm}$. Analisis EDS pula membuktikan bahawa peratusan atomik meningkat apabila kepekatan Ag yang lebih tinggi digunakan dengan nilai 5.6 at.\% dan 16.1 at.\% bagi sampel $0.05 \mathrm{M}$ dan $0.1 \mathrm{M} \mathrm{ZnO}$ berstruktur mikro diubahsuai dengan $\mathrm{Ag}$ berstruktur nanopartikel. Pewarna metilena biru (MB) digunakan sebagai contoh pencemaran warna untuk mengkaji aktiviti penurunan foto pemangkin. ZnO berstruktur mikro diubahsuai dengan Ag berstruktur nanopartikel menunjukkan aktiviti penurunan foto yang lebih baik daripada $\mathrm{ZnO}$ tulen. Keputusan menunjukkan bahawa peningkatan dalam pemalar kadar penurunan foto, $k$ diperoleh apabila kepekatan Ag lebih tinggi digunakan pada $\mathrm{ZnO}$ dengan nilai $0.016,0.026$ dan $0.032 \mathrm{~min}^{-1}$ untuk $\mathrm{ZnO}$ tulen, $0.05 \mathrm{M}$ dan $0.01 \mathrm{M} \mathrm{ZnO}$ berstruktur mikro diubahsuai dengan Ag berstruktur nanopartikel. Peningkatan nilai $k$ dengan kehadiran Ag disebabkan oleh 


\section{Hartini et al: PREPARATION AND CHARACTERIZATION OF Ag NANOPARTICLES DECORATED WITH ZnO MICROSTRUCTURES FOR THE CATALYTIC PHOTODEGRADATION OF METHYLENE BLUE DYE UNDER UV LIGHT IRRADIATION}

jangka hayat berpanjangan penghasilan foto oleh pasangan lubang dan elektron di ZnO hasil daripada Ag nanopartikel yang bertindak sebagai penerima elektron.

Kata kunci: Ag berstruktur nanopartikel, zink oksida, sol-gel, penurunan foto, metilena biru

\section{Introduction}

Recently, Zinc Oxide $(\mathrm{ZnO})$ has been widely investigated as one of the important material for photocatalytic applications due to its large initial rates of activities and having active sites with higher surface reactivity [1]. Combined with the advantages of non-toxicity, high sensitivity, stability, cost effective and environmental safety, $\mathrm{ZnO}$ has become a potential photocatalyst for remediation of environmental problem [2]. It is reported that, $\mathrm{ZnO}$ photocatalyst also presents some challenges such as fast recombination rate of the photogenerated electron-hole pair and low quantum efficiency, which resulting low photocatalytic efficiency reaction in the system [3,4]. Therefore, in order to improve the photocatalytic activities, researchers have been found that doping is one of the alternative ways to improve the photocatalytic properties. For instance, Changle $\mathrm{Wu}$ et al. reported that $\mathrm{Cu}$ doped $\mathrm{ZnO}$ can enhance the photocatalytic efficiency of $\mathrm{ZnO}$ under visible light irradiation [5], and Jing Zhao et al. reported that $\mathrm{Ni}$-doped $\mathrm{ZnO}$ nanorod exhibited higher photocatalytic activity than un-doped $\mathrm{ZnO}$ [6]. Incorporating and modifying silver in $\mathrm{ZnO}$ have been attract much interest in photocatalytic application due to more effective electron-hole separation of the $\mathrm{Ag} / \mathrm{ZnO}$ composite and $\mathrm{Ag}$ will increase the electron transfer process [7 - 9]. In this work, the photocatalytic activities of the pure $\mathrm{ZnO}$ and $\mathrm{AgNPs}$ decorated microstructured $\mathrm{ZnO}$ act as photocatalyst prepared by sol-gel method were studied by the degradation of methylene blue (MB) under ultraviolet irradiation.

\section{Synthesis of the photocatalyst}

\section{Materials and Methods}

$\mathrm{ZnO}$ and Silver nitrate $\left(\mathrm{AgNO}_{3}\right)$ were used as the starting materials for the synthesis of AgNPs decorated with $\mathrm{ZnO}$ microstructures by sol-gel method. Methylene blue dye (MB) was used as a representative organic pollutant in water. All materials used were of analytical grade and were used without any further purification. The stock solution was prepared by dissolved $5 \mathrm{~g}$ of $\mathrm{ZnO}$ powder that mixed with $\mathrm{AgNO}_{3}$ and $\mathrm{HMTA}$ at $0.05 \mathrm{M}$ and $0.1 \mathrm{M}$ concentration in $100 \mathrm{ml}$ of deionized water. The stock solution was then heated at $95{ }^{\circ} \mathrm{C}$ for 6 hours. After completion, the obtained white-greyish precipitates were rinsed repeatedly with deionized water and finally dried at $300{ }^{\circ} \mathrm{C}$ for 2 hours.

\section{Characterization methods}

The structural properties of the prepared samples of AgNPs decorated with $\mathrm{ZnO}$ microstructures were characterized by X-ray diffraction (XRD) recorded by PANalytical diffractometer using $\mathrm{Cu} K \alpha(\lambda=1.5406 \AA$ ), while the surface morphology of the samples was studied using field emission scanning electron microscope (FESEM). The composition analysis was performed by electron dispersive X-ray spectroscopy (EDS) attached to the FESEM. The optical absorbance properties of the catalyst were characterized by UV-Vis spectrophotometer.

\section{Photocatalytic measurement}

The photocatalytic activities of the samples were carried out by monitoring the photocatalytic degradation of MB dye in aqueous solution. $30 \mathrm{mg}$ of pure $\mathrm{ZnO}, 0.05 \mathrm{M}$ and $0.1 \mathrm{M} \mathrm{AgNPs}$ decorated microstructures $\mathrm{ZnO}$ act as a catalyst were placed into a beaker containing $10 \mathrm{mg} / \mathrm{L} \mathrm{MB}$ dye solution. Prior to the irradiation, the mixture was stirred in the dark for 30 minutes to establish an adsorption/ desorption equilibrium. The solution then was irradiated under ultraviolet (UV) light (main wavelength: $254 \mathrm{~nm}$ ). After irradiating for 10, 20, 30, 40, 50 and 60 minutes, a certain amount of solutions was collected and the concentration of residual MB was determined by the absorption of the reaction solution at the characteristic absorption wavelength $664 \mathrm{~nm}$ using UV-visible spectrophotometer.

\section{Results and Discussion}

Figure 1 shows the FESEM images of (a) pure $\mathrm{ZnO}$, (b) $0.05 \mathrm{M}$ AgNPs decorated microstructures $\mathrm{ZnO}$, (c) $0.1 \mathrm{M}$ AgNPs decorated microstructures $\mathrm{ZnO}$ and (d) the EDS spectra of selected area of all samples. The images clearly revealed that all samples composed of rod-like and cubic-like particles with average size about $100-500 \mathrm{~nm}$. In addition, the morphology and size of the photocatalyst do not show significant changes when Ag was introduced. 


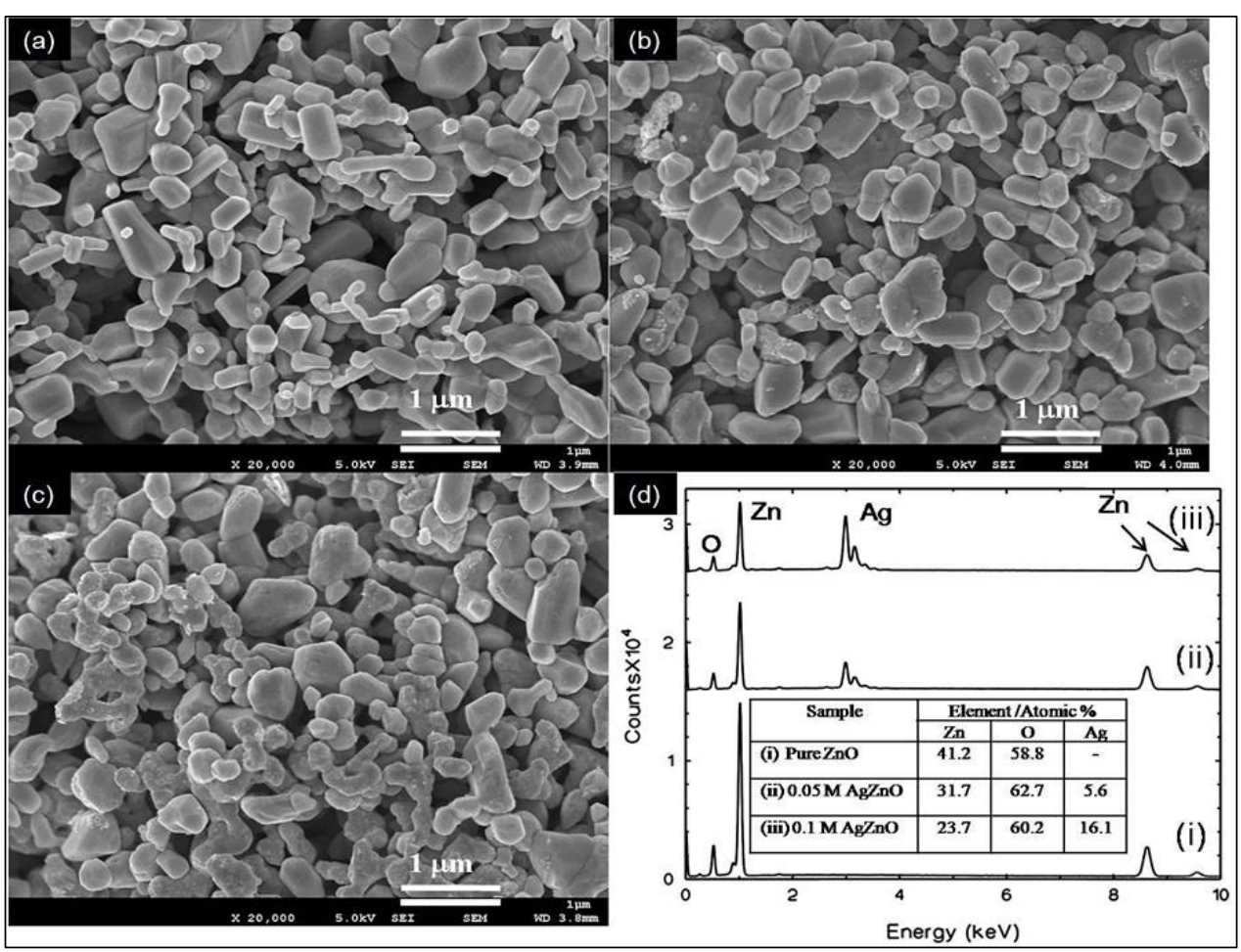

Figure 1. FESEM images of (a) pure $\mathrm{ZnO}$, (b) $0.05 \mathrm{M}$ AgNPs decorated microstructures $\mathrm{ZnO}$, (c) 0.1M AgNPs decorated microstructures $\mathrm{ZnO}$ and (d) the corresponding EDS analysis

However, from the EDS analysis confirmed that Ag element was detected in sample AgNPs decorated microstructures $\mathrm{ZnO}$, shown in Figure 1 (b) and (c), respectively. As can be seen from the EDS graph, Ag was incorporated in the samples and the atomic percentage of Ag increased as higher concentration was applied with value of 5.6 at.\% and 16.1 at.\% for sample $0.05 \mathrm{M}$ and $0.1 \mathrm{M}$ AgNPs decorated microstructures $\mathrm{ZnO}$. Besides, there was no other impurities was detected as EDS analysis of the sample only composed the element of Zn, O, and Ag.

Figure 2 shows the normalized XRD patterns for (a) pure $\mathrm{ZnO}$, (b) $0.05 \mathrm{M}$ AgNPs decorated microstructures $\mathrm{ZnO}$ and (c) $0.1 \mathrm{M}$ AgNPs decorated microstructures $\mathrm{ZnO}$. All the diffraction peaks are corresponding to the hexagonal wurtzite $\mathrm{ZnO}$ and cubic metallic Ag crystal structure (labelled as * in the graph) respectively. No other peak was detected and there was no significant shift for all diffraction peaks indicating that the silver did not substitutes for $\mathrm{Zn}^{2+}$ or interstitial atom [9] and suggested that the silver just decorated on the surface [10].

The photocatalytic degradation of the pure $\mathrm{ZnO}$ and AgNPs decorated microstructures $\mathrm{ZnO}$ in $\mathrm{MB}$ dye solution is shown in Figure 3 (a) - (d). From the time dependent absorbance spectra, the absorbance peak at $664 \mathrm{~nm}$ was reduced significantly, indicating the degradation of the dye molecule. It can be seen from Figure 3, AgNPs decorated microstructures $\mathrm{ZnO}$ showed a remarkable enhancement of photocatalytic activity compared with pure $\mathrm{ZnO}$ particles. Moreover, $0.1 \mathrm{M}$ AgNPs decorated microstructures $\mathrm{ZnO}$ show the highest catalytic activity compared to $0.05 \mathrm{M}$ AgNPs decorated microstructures $\mathrm{ZnO}$ and pure $\mathrm{ZnO}$ particles. The photocatalytic degradation of MB can be described to a linear pattern using pseudo-first kinetics model as stated in Equation (1):

$$
\ln \left(\mathrm{C} / \mathrm{C}_{0}\right)=-\mathrm{kt}
$$

where $k$ is the degradation rate constant, $\mathrm{C}_{0}$ and $\mathrm{C}$ are the $\mathrm{MB}$ initial concentration and the concentration of solution after the degradation time of $t$, respectively. 


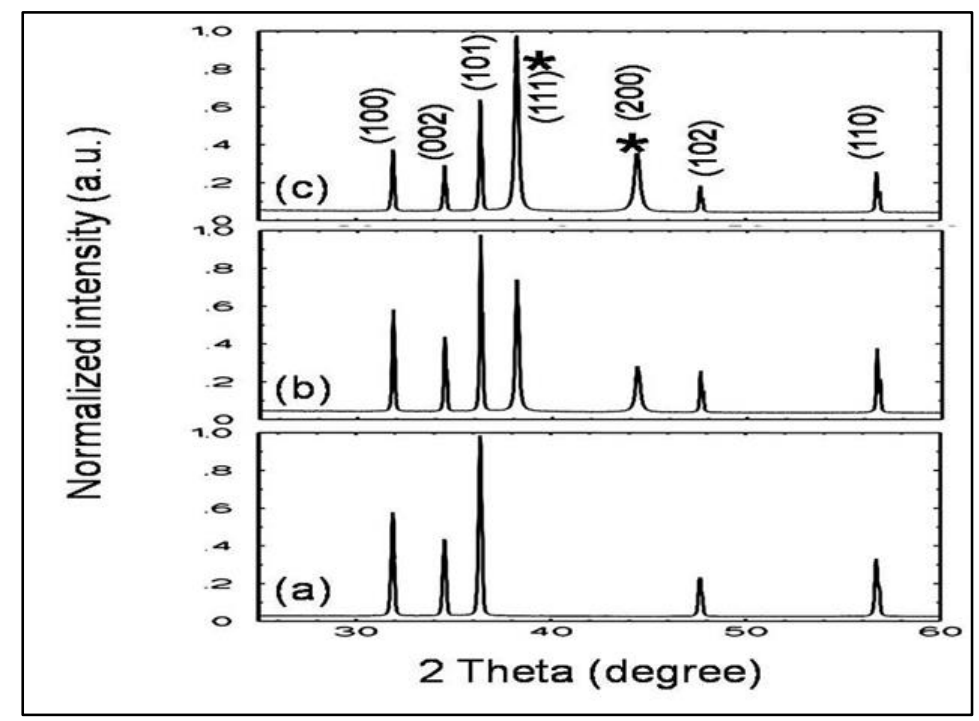

Figure 2. Normalized XRD patterns of the (a) pure $\mathrm{ZnO}$, (b) 0.05M AgNPs decorated microstructures $\mathrm{ZnO}$ and (c) $0.1 \mathrm{M} \mathrm{AgNPs}$ decorated microstructures $\mathrm{ZnO},(\mathrm{Ag}$ labelled as * in the graph)

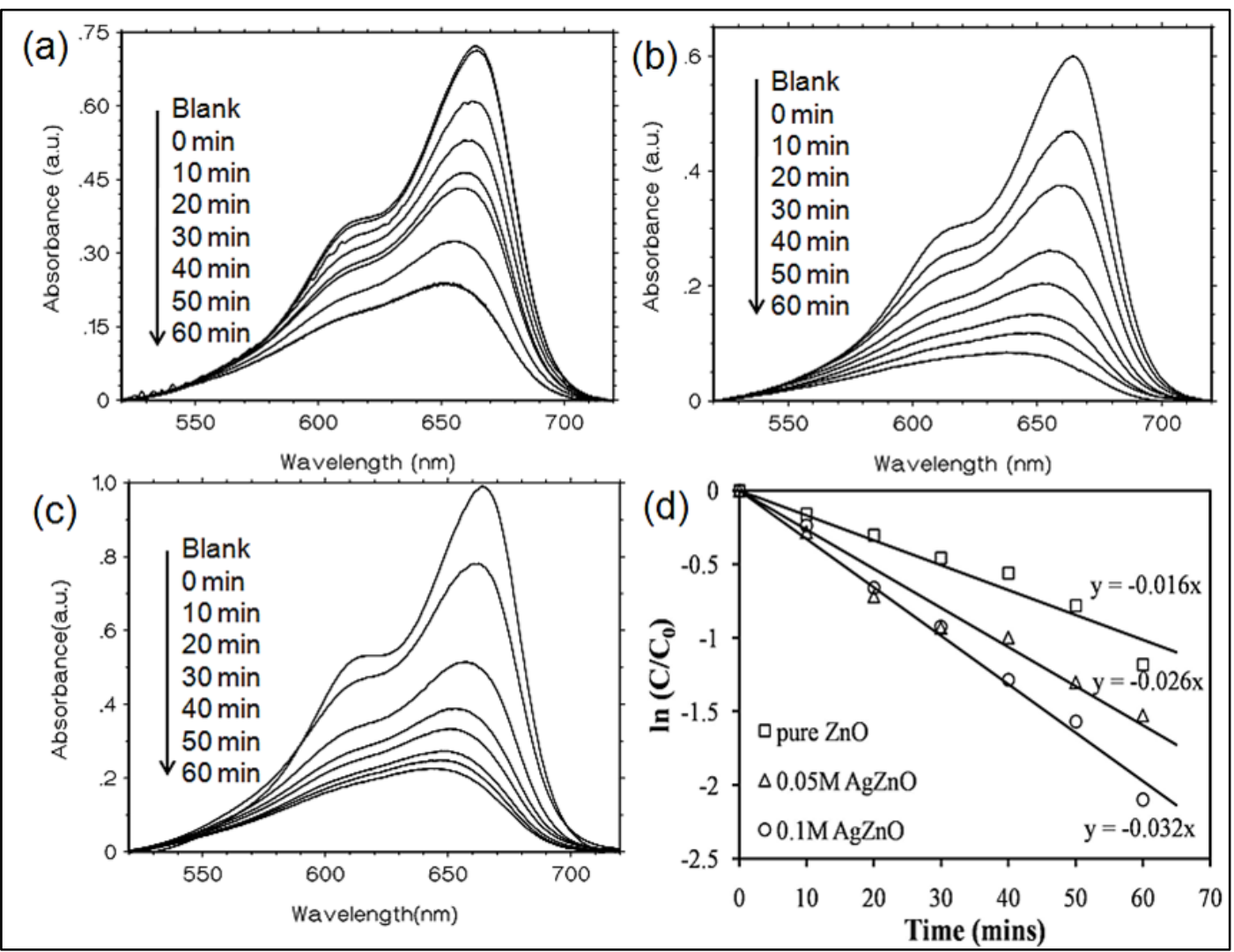

Figure 3. UV-Vis absorption spectral changes of MB under UV light irradiation by (a) pure ZnO, (b) $0.05 \mathrm{M} \mathrm{AgNPs}$ decorated microstructures $\mathrm{ZnO}$, (c) $0.1 \mathrm{M}$ AgNPs decorated microstructures $\mathrm{ZnO}$ and (d) $\mathrm{MB}$ photodegradation curves of $\ln \mathrm{C} / \mathrm{C}_{0}$ versus time for all photocatalyst 
The obtained results are shown in Figure 3(d) where the photodegradation rate constant, $k$ of different photocatalyst were $0.016,0.026$ and $0.032 \mathrm{~min}^{-1}$ for pure $\mathrm{ZnO}, 0.05 \mathrm{M}$ and $0.1 \mathrm{M}$ AgNPs decorated microstructures $\mathrm{ZnO}$, respectively. Therefore, it can be seen that the photocatalytic activities efficiency of MB molecules increases in the following order: pure $\mathrm{ZnO}<0.05 \mathrm{M}$ AgNPs decorated microstructures $\mathrm{ZnO}<0.1 \mathrm{M}$ AgNPs decorated microstructures $\mathrm{ZnO}$. In addition, the results showed that MB solution greatly degrade in the presence of AgNPs decorated microstructures $\mathrm{ZnO}$ and the rate constant is much higher using 0.1M AgNPs decorated microstructures $\mathrm{ZnO}$. This significant effect of AgNPs decorated microstructures $\mathrm{ZnO}$ is possibly due to the efficient charge electron-hole separation of $\mathrm{Ag}$ and $\mathrm{ZnO}[11-13]$.

Generally, on semiconductor surface Ag having a characteristic like an electron sinks, which provide sites for the accumulation of photogenerated electrons, and then improve the separation of photogenerated electrons and holes $[13,14]$. In addition, the electron pairs lifetime can be prolong and thus can enhance the photocatalytic activity of $\mathrm{AgZnO}$ photocatalyst [11]. Other than that, higher dispersity of $\mathrm{Ag}$ particles on the $\mathrm{ZnO}$ surfaces also gives higher photocatalytic activity of AgNPs decorated microstructures $\mathrm{ZnO}$. Ag particles have a higher Fermi energy level compared to $\mathrm{ZnO}$, caused a movement of electrons from $\mathrm{Ag}$ to the conduction band (CB) of $\mathrm{ZnO}$ in order to achieve Fermi energy level equilibrium $\left(\mathrm{E}_{\mathrm{f}}\right)$.

\section{Conclusion}

The AgNPs decorated microstructures $\mathrm{ZnO}$ were successfully prepared by sol-gel method. After comparison with pure $\mathrm{ZnO}$ particles, AgNPs decorated microstructures $\mathrm{ZnO}$ exhibited better photocatalytic activity with photodegradation rate constant, $k$ value of $0.016,0.026$ and $0.032 \mathrm{~min}^{-1}$ for pure $\mathrm{ZnO}, 0.05 \mathrm{M}$ and $0.1 \mathrm{M}$ AgNPs decorated microstructures $\mathrm{ZnO}$, respectively. The enhance performance of AgNPs decorated microstructures $\mathrm{ZnO}$ shows that it can be used as an alternative photocatalyst for remediation of environmental problem.

\section{Acknowledgement}

This work is funded by the University of Malaya under the UM Research Grant No. RG247-12AFR and PPP Grant No. PG068-2013A.

\section{References}

1. Chang, C.-W., Wu, H.-T., Huang, S.-H., Chen, C.-K., Un, I.-W. and Yen, T.-J. (2013). Single-crystalline heterostructure of $\mathrm{ZnO}$ nanowire arrays on large $\mathrm{Ag}$ microplates and its photocatalytic activity. Acta Materialia, 61(18): 6993-6999.

2. Stephen, J. P., David, P. N., Matt, P. I., Art, F. H., John, M. Z., Weimin, M. C. and Irina A. B. (2007). ZnO Doped With Transition Metal Ions. IEEE Transactions on Electron Devices, 54(5): 1040-1048.

3. Subash, B., Krishnakumar, B., Sreedhar, B., Swaminathan, M. and Shanthi, M. (2013). Superlattices and microstructures highly active $\mathrm{WO}_{3}-\mathrm{Ag}-\mathrm{ZnO}$ photocatalyst driven by day light illumination. Superlattices and Microstructures, 54: 155-171.

4. Han, Z., Ren, L., Cui, Z., Chen, C., Pan, H. and Chen, J. (2012). Applied Catalysis B : Environmental Ag/ZnO flower heterostructures as a visible-light driven photocatalyst via surface plasmon resonance. Applied Catalysis B: Environmental, 126: 298-305.

5. Wu, C., Shen, L., Zhang, Y.-C., Huang, Q. and Yu, H. (2011). Solvothermal synthesis of Cu-doped ZnO nanowires with visible light-driven photocatalytic activity. Materials Letters, 74(12): 236-238.

6. Zhao, J., Wang, L., Yan, X., Yang, Y., Lei, Y., Zhou, J., Huang, Y. and Gu, Y. (2011). Structure and photocatalytic activity of Ni-doped ZnO nanorods. Materials Research Bulletin, 46(8): 1207-1210.

7. Zhang, D., Liu, X. and Wang, X. (2011). Growth and photocatalytic activity of ZnO nanosheets stabilized by Ag nanoparticles. Journal of Alloys and Compounds, 509(15): 4972-4977.

8. Changdong, G., Chun, C., Haiyou, H., Tailun, W., Ning, W. and Tong-Yi, Z. (2009). Growth and photocatalytic activity of dendrite-like ZnO @ Ag. Crystal Growth \& Design, 9(7): 3278-3285.

9. Georgekutty, R., Seery, M. K. and Pillai, S. C. (2008). A highly efficient Ag-ZnO photocatalyst: Synthesis, properties, and mechanism. Journal of Physical Chemistry C, 112(35): 13563-13570.

10. Yang, Z., Zhang, P., Ding, Y., Jiang, Y., Long, Z. and W. Dai. (2011). Facile synthesis of Ag/ZnO heterostructures assisted by UV irradiation: Highly photocatalytic property and enhanced photostability. Materials Research Bulletin, 46(10):1625-163. 
Hartini et al: PREPARATION AND CHARACTERIZATION OF Ag NANOPARTICLES DECORATED WITH ZnO MICROSTRUCTURES FOR THE CATALYTIC PHOTODEGRADATION OF METHYLENE BLUE DYE UNDER UV LIGHT IRRADIATION

11. Chai, B., Wang, X., Cheng, S., Zhou, H. and Zhang, F. (2014). One-pot triethanolamine-assisted hydrothermal synthesis of $\mathrm{Ag} / \mathrm{ZnO}$ heterostructure microspheres with enhanced photocatalytic activity. Ceramic International, 40(1): 429-435.

12. Lin, D., Wu, H., Zhang, R. and Pan, W. (2009). Enhanced photocatalysis of electrospun Ag-ZnO heterostructured nanofibers. Chemistry of Materials, 21(15): 3479-3484.

13. Gao, S., Jia, X., Yang, S., Li, Z. and Jiang, K. (2011). Hierarchical Ag/ZnO micro/nanostructure: Green synthesis and enhanced photocatalytic performance. Journal of Solid State Chemistry, 184(4): 764-769.

14. Rezaei, M. and Habibi-yangjeh, A. (2013). Microwave-assisted preparation of Ce-doped ZnO nanostructures as an efficient photocatalyst. Materials Letters, 110: 53-56. 